\title{
Inhibition of $\beta$-Cyanoalanine Synthase Activity by Growth Inhibitors from Peach Roots
}

\author{
Fusao Mizutani, Ryuji Hirota and Kazuomi Kadoya \\ College of Agriculture, Ehime University \\ Tarumi, Matsuyama 790
}

\begin{abstract}
Summary
The effect of growth inhibitors from peach roots on the activity of $\beta$-cyanoalanine synthase was investigated. A positive correlation was found between the condensed tannin content and the inhibition of $\beta$-cyanoalanine synthase activity in the fractions of extract of peach roots. Ethyl-acetate-soluble neutral fraction, which showed the highest content of condensed tannins and the greatest inhibition of the enzyme activity, was further separated by Sephadex LH-20 column chromatography. Fractions containing high condensed tannins reduced the growth of rice seedlings and suppressed the activity of $\beta$-cyanoalanine synthase. One of the purified biflavanols, which were isolated from peach roots as growth inhibitors, also inhibited the $\beta$-cyanoalanine synthase activity. We inferred that when the growth inhibitors suppress this activity, the normal cyanide metabolism is disturbed, resulting in the accumulation of hydrogen cyanide in the tissues. Thus from an allelopathic point of view, the growth inhibitors derived from the root residues of preplanted peach trees adversely affect the growth of replanted trees by causing cyanogenesis in their roots.
\end{abstract}

\section{Introduction}

The peach replant problem has been studied from an allelopathic point of view by many investigators $(6,8,10,13,14,18,19,20)$. We previously reported that condensed tannins are possibly involved in the reduced growth of peach trees on replanted sites(13), together with the hydrolyzed derivatives of the cyanogenic glucoside (prunasin) such as hydrogen cyanide, benzaldehyde, and benzoic $\operatorname{acid}(6,8,14,18,20)$.

Ohigashi et al. identified three flavanols as growth inhibitors from peach roots(19). Two of them are biflavanols which yield anthocyanidin-like substances when boiled in conc $\mathrm{HCl}$, indicating condensed tannins.

Cyanogenic glucosides are not end products of plant metabolism but an active turnover takes place in the cyanogenic plants. In general, amino acids are principal precursors

Received for publication September 5, 1986.

Studies on the soil sickness problem for peach trees III. of cyanogenic glucosides $(3,4)$. Hydrogen cyanide derived from the hydrolysis of the glucosides is effectively incorporated again into amino acid metabolism. $\beta$-Cyanoalanine synthase catalyzes the reaction between hydrogen cyanide and $\mathrm{L}$-cysteine to form $\beta$ cyanoalanine $(1,7,9)$. Thus the enzyme is considered to play a role of detoxifying hydrogen cyanide in the tissues.

The object of this study is to elucidate the effect of growth inhibitors from peach roots on the activity of $\beta$-cyanoalanine synthase.

\section{Materials and Methods}

Extraction and fractionation of growth inhibitors from peach roots

Twenty $g$ of peach roots were extracted in $80 \%$ methanol. The extract was evaporated in vacuo to aqueous phase. The $\mathrm{pH}$ of the aqueous phase was adjusted to 3.0 with $0.1 \mathrm{~N} \mathrm{H}_{2} \mathrm{SO}_{4}$ and partitioned against chloroform, ethyl acetate, and n-butanol, successively, as shown in Fig. 1.

An aliquot of the ethyl acetate fraction, 


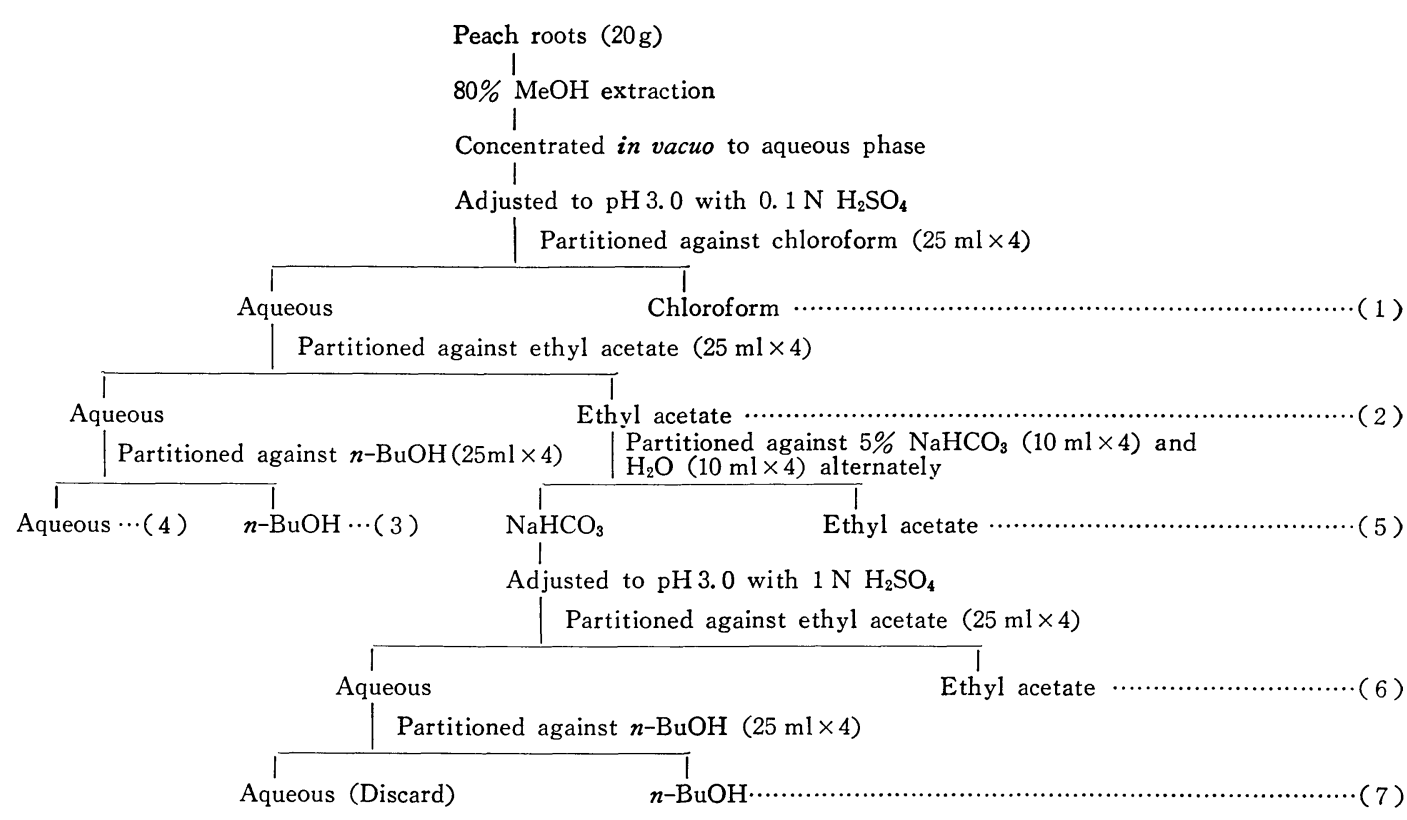

Fig. 1. Fractionation of the methanolic extract of peach roots by partitioning against various solvents.

equivalent to $15 \mathrm{~g}$ f.w. roots, was further partitioned against 5\% $\mathrm{NaHCO}_{3}$ and distilled water, alternately, and the extracts were combined. The $\mathrm{pH}$ of the aqueous phase was lowered to 3.0 with $1 \mathrm{~N} \mathrm{H}_{2} \mathrm{SO}_{4}$ and partitioned against ethyl acetate and n-butanol.

Further, an aliquot of the ethyl-acetatesoluble neutral fraction (Fraction number 5 in Fig. 1), equivalent to $10 \mathrm{~g} \mathrm{f}$. w. roots, was subjected to Sephadex LH-20 column chromatography $(1 \mathrm{~cm} \times 26 \mathrm{~cm})$ with $70 \%$ methanol as eluent. Fractions of $10 \mathrm{ml}$ were collected and total volume of the eluent was $400 \mathrm{ml}$.

\section{Analysis of condensed tannins}

An aliquot of each fraction equivalent to $0.1 \mathrm{~g} \mathrm{f.w.} \mathrm{roots} \mathrm{was} \mathrm{taken} \mathrm{in} \mathrm{a} \mathrm{test} \mathrm{tube} \mathrm{and}$ dried in a stream of air. Two $\mathrm{ml}$ of $2 \mathrm{~N}$ $\mathrm{HCl}$ were added to the test tube and boiled for $30 \mathrm{~min}$. After cooling, anthocyanidin was extracted 4 times with $4 \mathrm{ml}$ isoamylalcohol. The extracts were combined and diluted two-fold with the same solvent, and the content of anthocyanidin was measured spectrophotometrically at $545 \mathrm{~nm}$; the reading was expressed as the relative concentration of condensed tannins(13).

\section{Bioassy for growth inhibitors (rice seedling test)}

Seeds of rice (Oryza sativa L. 'Tanginbouzu') were immersed in $\mathrm{NaCl}$ solution with a specific gravity of 1.05 and heavy seeds of uniform size were selected. These seeds were sterilized in $1 \%$ sodium hypochlorite for $30 \mathrm{~min}$, then washed in tap water and allowed to germinate in a petri dish at $30^{\circ} \mathrm{C}$. After 5 days, seedlings with coleoptiles about $1 \mathrm{~mm}$ in length were selected and subjected to bioassay. An aliquot of each chromatographic fraction, equivalent to $0.4 \mathrm{~g} \mathrm{f.w}$. roots, was taken in a glass vial $(6 \mathrm{~cm}$ length $\times 3 \mathrm{~cm}$ inner diameter) and dried in air. One $\mathrm{ml}$ of distilled water was added and 7 seedlings were then placed in the vial. The vial was sealed with plastic film and exposed to continuous florescent light at $2000 \mathrm{lux}$ at $30^{\circ} \mathrm{C}$. When the third leaf emerged in the control plots, the length of second leaf sheath and the longest root was measured. The results were expressed as percentage of the controls.

Preparation and assay for $\beta$-cyanoalanine synthase

Seeds of Japanese apricot (Prunus mume Sieb. \& Zucc.) stratified at $5^{\circ} \mathrm{C}$ were used for the preparation of the enzyme. Seeds 
(260 mg f.w.) were homogenized with a precooled mortar and pestle. The homogenate was taken in $25 \mathrm{ml}$ cold Tris- $\mathrm{HCl}$ buffer ( 50 $\mathrm{mM}, \mathrm{pH} \mathrm{8.5)}$ and centrifuged at $12,000 \times \mathrm{g}$ at $4^{\circ} \mathrm{C}$. The supernatant was used as the crude enzyme extract. Aliquot samples from each partitioned fraction (equivalent to $0.1 \mathrm{~g}$ f. w. roots) or chromatographically separated fraction (equivalent to $0.4 \mathrm{~g} \mathrm{f}$. w. roots) were taken in test tubes and dried in air. A 0.5 $\mathrm{ml}$ quantity of $50 \mathrm{mM}$ Tris- $\mathrm{HCl}$ buffer $(\mathrm{pH}$ 8.5 ) and $0.5 \mathrm{ml}$ of the crude enzyme extract were added. Each $0.5 \mathrm{ml}$ of $100 \mathrm{mM} \mathrm{L-cys-}$ teine and $50 \mathrm{mM} \mathrm{NaCN}$ which were dissolved in $100 \mathrm{mM}$ Tris-buffer ( $\mathrm{pH} 8.5$ ) were then added and the test tubes were incubated at $30^{\circ} \mathrm{C}$ for one hour. The reaction was stopped by the addition of $0.5 \mathrm{ml}$ of $0.02 \mathrm{M} \mathrm{N}, N-$ dimethyl-p-phenylenediamine sulfate in 7.2 $\mathrm{N} \mathrm{HCl}$ and $0.5 \mathrm{ml}$ of $0.03 \mathrm{M}$ ferric chloride in $1.2 \mathrm{~N} \mathrm{HCl}$. The samples were then centrifuged at $1,050 \times \mathrm{g}$ for $5 \mathrm{~min}$ to remove precipitated proteins; absorbance at $650 \mathrm{~nm}$ was recorded using a Hitachi photo-electric spectrophotometer (EPU-2). Sodium sulfide was used as the standard reference. Identical assays lacking substrates and containing boiled enzyme were used as control.

\section{Results and Discussion}

An apparent positive correlation was found between the content of condensed tannins and the inhibition of $\beta$-cyanoalanine synthase activity among the overall partitioned fractions as shown in Fig. 2. Fractions 2 and 5 had high condensed tannin contents and greatly suppressed the enzyme activity. We previously reported that these fractions had a high content of condensed tannin and inhibited the growth of shoots and roots of rice seedlings as well(13).

The ethyl-acetate-soluble neutral fraction (Fraction 5), which showed the greatest inhibition for the enzyme activity (Fig. 2) was further separated by Sephadex LH-20 column chromatography. Each fraction was analyzed for condensed tannins and subjected to the rice seedling test and enzyme assay. The results were shown in Fig. 3. Fractions of $90 \sim 130 \mathrm{ml}$ showed high content of con-

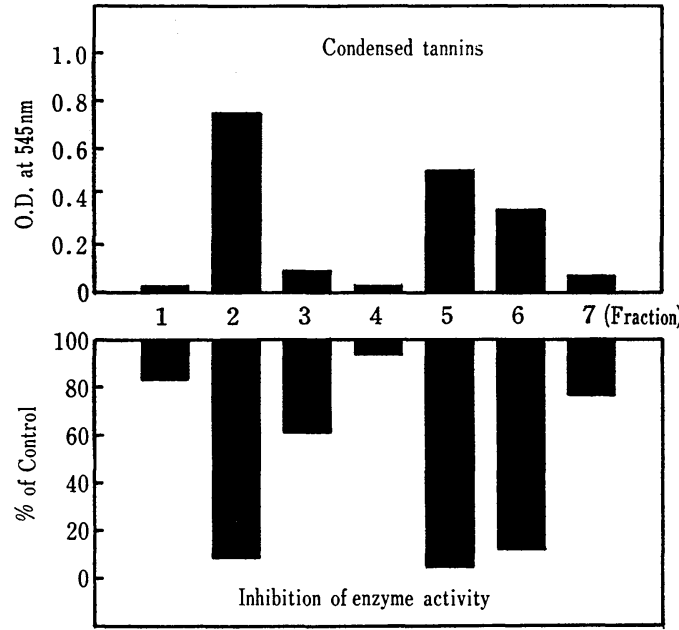

Fig. 2. Content of condensed tannins and inhibition of $\beta$-cyanoalanine synthase activity in various fractions. For details of the fractions, see Fig.1.

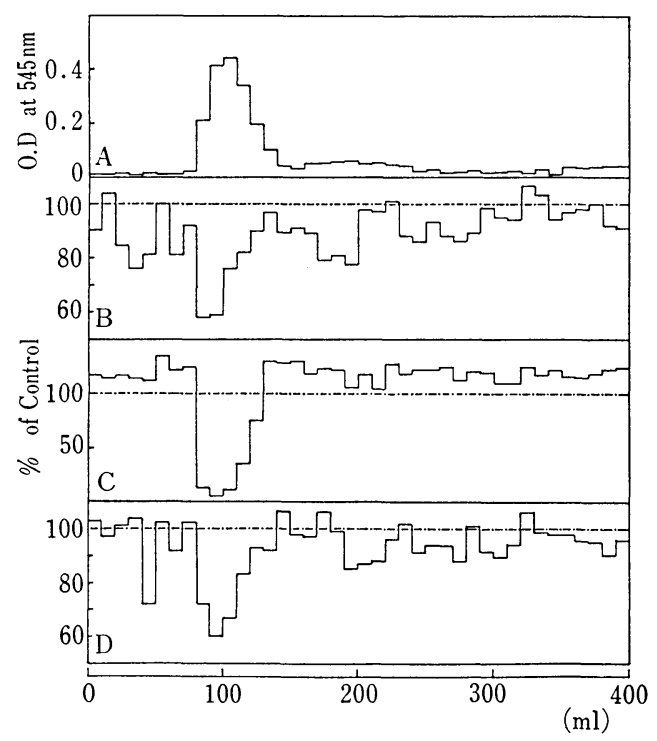

Fig. 3. Separation of ethyl-acetate-soluble neutral fraction (Fraction No.5) by Sephadex LH-20 column chromatography.

A : Condensed tannin content

$B$ : Second leaf-sheath length of rice seedlings

$C:$ Longest root length of rice seedlings

$\mathrm{D}: \beta$-Cyanoalanine synthase activity

An extract equivalent to 0.1 and $0.4 \mathrm{~g} f w$ of peach root was used for assay for $\mathrm{A}$ and the others, respectively.

densed tannins, growth inhibition of rice seedlings, and suppression of the enzyme activity.

Ohigashi et al. (19) identified three flava- 


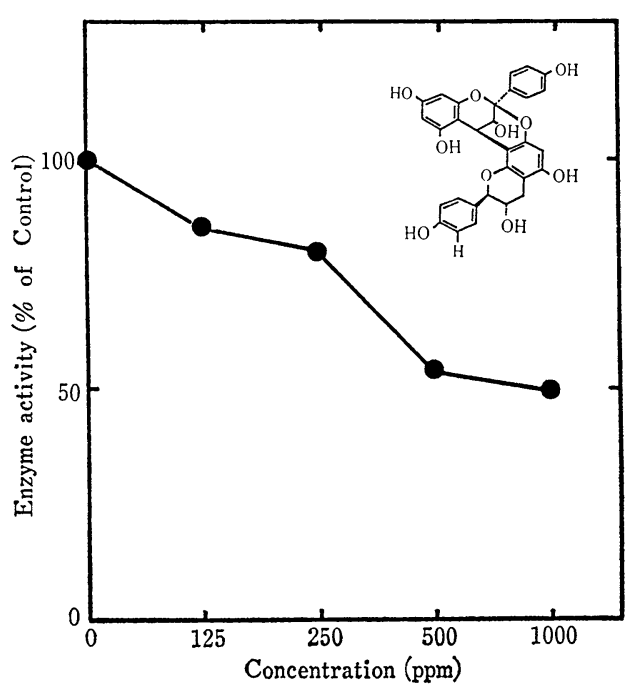

Fig. 4. Effect of one of the purified biflavanols isolated from peach roots on the activity of $\beta$-cyanoalanine synthase.

nols as growth inhibitors from peach roots: two of them are biflavanol and the other one is $(t)$-afzelechin. Since the biflavanols yield anthocyanidin-like substances when heated in conc $\mathrm{HCl}$, which is typical for condensed tannins, these are probably major constituents of the growth inhibiting fractions in the present experiment. One of the flavanols was examined as to whether it actually inhibits the activity of $\beta$-cyanoalanine synthase (Fig. 4). It suppressed the enzyme activity about $50 \%$ at $500 \mathrm{ppm}$. We previously reported that this flavanol also inhibited the root growth of peach seedlings by 23,65 , and $88 \%$ at 100,500 and 1000 ppm, respectively, when assayed aseptically on agar media (13).

Furthermore, when an aliquot of the fractions of $90 \sim 130 \mathrm{ml}$ was sujected to thin layer chromatography (Wakogel B-5 FM $5 \times 20 \mathrm{~cm}$, solvent; chloroform : acetone : acetic acid $=$ $50: 50: 1$ ), several spots were detected under ultra violet light; these showed the property of condensed tannins. Thus some other related compounds, having similar structures to the biflavanols identified by Ohigashi et al. (19), seem to be involved in the fractions.

The fraction of eluent volume of $40 \mathrm{ml}$ also showed the inhibition of the growth of second leaf sheath of rice seedlings and $\beta$ cyanoalanine synthase activity (Fig. 3). When this fraction was further separated by thin layer chromatography with similar running conditions to those described above, two spots were detected under ultra violet light. However, these compounds did not yield anthocyanidin-like substances when heated in conc $\mathrm{HCl}$; apparently they are not condensed tannins. They may be (+)-afzelechin or its related compounds.

$\beta$-Cyanoalanine synthase plays a role in metabolizing $\mathrm{HCN}$ which was exogenously administered to plant tissues, as well as $\mathrm{HCN}$ produced endogenously by the hydrolysis of cyanogenic glucosides. In cyanogenic plants, cyanogenic glucosides are not end products of metabolism but an active turnover takes place. Most cyanogenic glucosides are biosynthesized from amino acids via aldoxime, nitrile, and $\alpha$-hydroxynitrile $(3,4)$. Further, HCN produced upon degradation of the glucosides is effectively incorporated as $\beta$-cyanoalanine, which is in turn converted to asparagine(2). Thus, cyanogenic glucosides are considered to be one of the intermediates in the amino acid metabolism in cyanogenic plants.

Rowe and Catlin(21) reported that roots of peach, apricot and plum produced hydrogen cyanide when exposed to anaerobic conditions. We also confirmed that whereas peach roots produced hydrogen cyanide under $\mathrm{N}_{2}$ gas conditions, aeration suppressed the cyanogenesis(10). Furthermore, we reported that respiratory inhibitors such as monoiodoacetate, iodoacetamide and sodium azide effectively cause root cyanogenesis in peach trees (11). Rowe and Catlin(21) suggested that anaerobic conditions lead to the disorganization of membrane structures as a result of deletion of energy which is required for retaining membrane integrity; consequently contact between the substrate and the hydrolytic enzyme results in the production of hydrogen cyanide. Besides such an explanation, we proposed another possible interpretation from the kinetic aspect, that anaerobic conditions inhibit the metabolism of hydro- 
gen cyanide and as a result hydrogen cyanide is released from the normal metabolic process. In fact, Fowden and Bell(5) demonstrated that anaerobic conditions inhibit the incorporation of exogenously applied radioactive hydrogen cyanide by Chlorella pyrenoidosa. If the activity of $\beta$-cyanoalanine synthase, which effectively metabolizes hydrogen cyanide, is suppressed by certain internal or external factors, hydrogen cyanide will be released from normal metabolic processes. We previously suggested that peach trees replanted on old sites may cause cyanogenesis in their own roots by growth inhibitors derived from the root residues of preplanted trees (11). The present results provide evidence that the growth inhibitors from peach roots inhibit the activity of $\beta$-cyanoalanine synthase. Thus it is reasoned that the inhibition of $\beta$-cyanoalanine synthase activity leads to root cyanogenesis resulting in the suppression of physiological function of the roots and subsequently in the reduced growth of replanted peach trees.

However, causes for peach replant prob lems have been studied from many different points of view such as nematodes $(15,16,17)$, fungi $(22,23)$ and allelopathins $(6,8,10,13,14$, $18,19,20)$. Therefore, it seems most reasonable that while in some cases a certain single factor may be predominant, in other cases other factors may complicate the problems. Nevertheless, if allelopathins such as biflavanols are major factors in the replant sites, the above-mentioned mechanism will operate to cause the replant injuries.

\section{Literature Cited}

1. Blumenthal, S. G., H. R. HendRickson, Y.P. ABROL and E. E. CoNN. 1968. Cyanide metabolism in higher plants. III. The biosynthesis of $\beta$-cyanoalanine. J. Biol. Chem. $243: 5302-5307$.

2. CASTRIC, P. A., K. J. F. FARDEN and E. E. ConN. 1972. Cyanide metabolism in higher plants. $\mathrm{V}$. The formation of asparagine from $\beta$ cyanoalanine. Arch. Biochem. Biophys. $151: 62-69$.

3. ConN, E. E. 1979. Biosynthesis of cyanogenic glycosides. Naturwiss. $66: 28-34$.

4. EYJólFsSON, R. $1970 . \quad$ Recent advances in the chemistry of cyanogenic glycosides. Forsh. Chem. Org. Natur. $28: 74-108$.

5. Fowden, L. and E. A. Bell. 1965. Cyanide metabolism by seedlings. Nature 206:110112.

6. Hatsuda, Y., S. Murao, N. Terashima and T. YOKOTA. 1960. Biochemical studies on the soil sickness. Part II. On the toxic substance in peach roots. J. Agr. Chem. Soc. Japan $34:$ 486-488. (In Japanese).

7. HENDRICKSON, H. R. and E. E. CONN. 1969. Cyanide metabolism in higher plants. IV. Purification and properties of $\beta$-cyanoalanine synthase of blue lupine. J. Biol. Chem. $244: 2632-2640$.

8. Hirano, S. 1966. Studies on the peach sick soil. Doctoral thesis, Kyoto Univ. Kyoto. pp. 1-216. (In Japanese).

9. Miller, J. M. and E. E. Conn. 1980. Metabolism of hydrogen cyanide by higher plants. Plant Physiol. 62 : 1199-1202.

10. Mizutani, F., A. Sugiura and T. Tomana. 1977. Studies on the soil sickness problem for peach trees. I. Cyanogenesis involved in the relationships between root sensitivity to waterlogging and soil sickness. J. Japan. Soc. Hort. Sci. $46: 9-17$. (In Japanese with English summary).

11. Mizutani, F., A. Sugiura and T. Tomana. 1978. Root cyanogenesis of Prunus species as affcted by respiratory inhibitors and some chemicals. J. Japan. Soc. Hort. Sci. 47 : 443-447.

12. Mizutani, F., M. Yamada, A. Sugiura and T. TOMANA. 1979. The distribution of prunasin and amygdalin in Prunus species. Mem. Coll. Agr. Kyoto Univ. $113: 53-65$.

13. Mizutani, F., H. Itamura, A. Sugiura and T. TOMANA. 1979. Studies on the soil sickness problem for peach trees. II. Condensed tannins as growth inhibitors from peach roots. J. Japan. Soc. Hort. Sci. $48: 279-287$. (In Japanese with English summary).

14. Mizutani, F. 1980. Studies on the replant problem and water tolerance of peach trees. Mem. Coll. Agr. Ehime Univ. 24 : 115-198. (In Japanese with English summary).

15. Mountain, W. B. and H. R. BoyCE. 1958 a. The peach replant problem in Ontario. V. The relation of parasitic nematodes to regional differences in severity of peach replant failure. Can. J. Bot. $36: 125-134$.

16. Mountain, W. B. and H. R. BoyCe. 1958 b. The peach replant problem in Ontario. VI. The relation of Pratylenchus penetrans to 
the growth of young peach trees. Can. J. Bot. $36: 135-151$.

17. Mountain, W. B, and Z. A. Patrick. 1959. The peach replant problem in Ontario. VII. The pathogenecity of Pratylenchus penetrans (Cobb. 1917) Filip and Stek, 1941. Can. J. Bot. $37: 459-470$.

18. OH, S. D. and R.F. CARLSON. 1976. Water soluble extracts from peach plant parts and their effect on growth of seedling of peach, apple and bean. J. Amer. Soc. Hort. Sci. $101: 54-57$.

19. Ohigashi, H., S. Minami, H. Fukui, K. KoshimiZU, F. Mizutani, A. Sugiura and T. Tomana. 1982. Flavanols, as plant growth inhibitors from roots of peach, Prunus persica Batsh. cv. 'Hakuto'. Agric. Biol. Chem. 46 : 2555-2561.

20. Proebsting, F. L. and A: E. Gilmore, 1941.
The relation of peach root toxicity to the re-establishing of peach orchards. Proc. Amer. Soc. Hort. Sci. $38: 21-26$.

21. Rowe, R. N. and P. B. CATlin. 1971. Differential sensitivity to waterlogging and cyanogenesis by peach, apricot and plum roots. J. Amer. Soc. Hort. Sci. 96 : 305308.

22. SAvage, E. F., J. H. Weinberger, E. S. LUTTRELL and A.S. RHOADS. 1953. Clitocybe root rot-A disease of economic importance in Georgia peach orchards. Plant Disease Rep. $37: 269-270$.

23. WENSLEY, R. N. 1956. The peach replant problem in Ontario. IV. Fungi associated with replant failure and their importance in fumigated and nonfumigated soils. Can. J. Bot. 34 : $967-981$.

\title{
モモの根に含まれる生長抑制物質による $\beta$-シアノアラニン 合成酵素活性の抑制
}

水谷房雄・廣田龍司・門屋一臣

愛媛大学農学部 790 松山市樽味

\begin{abstract}
摘 要
モモの根に含まれる生長抑制物質が $\beta$-シアノアラニ ン合成酵素活性に及ぼす効果について調査した。モモの 根のアルニール抽出物を溶媒抽出法で種々の分画に分け て，それぞれの分画中の縮合性タンニン含量と酵素活性 の抑制度を比較したところ, 両者の間には正の相関があ った・最も縮合性タンニン含量が高く, 酵素活性の抑制度 の大きかった酢酸エチル可溶中性分画を更に Sephadex LH-20 カラムクロマトグラフィで分離したところ, 縮 合性タンニン含量が高い溶出分画でイネ実生の生長抑制 効果が大きく, $\beta$-シアノアラニン合成酵素の活性も抑 る biflavanols のうちの一つについて, 酵素活性に及ぽ す効果を調べたところ抑制効果が認められた．これらの 結果から, 青酸化合物を有する植物では, $\beta$-シアノア ラニン合成酵素の活性が抑制されると正常な青酸代謝が 阻害され，そのために組織中に青酸が蓄積するものと推 測された、モモのいや地をアレロパシーの観点から見る と, 前作のモモの根に由来する生長抑制物質が後作のモ モの根の青酸代謝を阻害することによって青酸が生し， これが後作のモモの生育阻害を引き起こしていると思わ れた。
\end{abstract}

